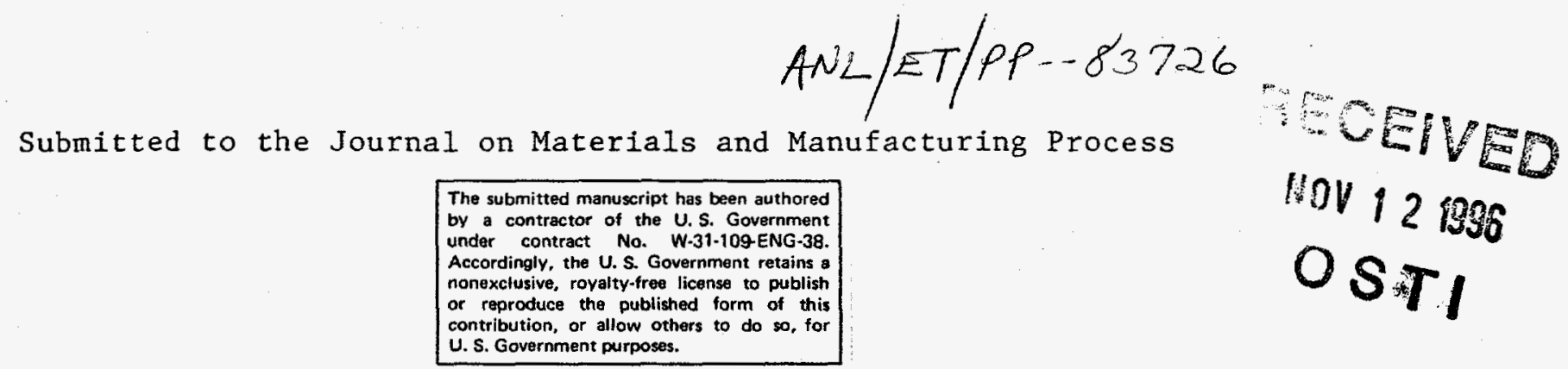

\title{
FABRICATION OF INTERMETALLIC COATINGS FOR ELECTRICAL INSULATION AND CORROSION RESISTANCE ON HIGH-TEMPERATURE ALLOYS
}

\author{
J.-H. Park and W. D. Cho ${ }^{\dagger}$ \\ Argonne National Laboratory, Argonne, IL 60439 \\ tDepartment of Metallurgical Engineering \\ University of Utah, Salt Lake City, UT 84112
}

\begin{abstract}
Several intermetallic films were applied to hightemperature alloys (vanadium alloys and 304 and 316 stainless steels) to provide electrical insulation and corrosion resistance. Alloy grain-growth behavior at $1000^{\circ} \mathrm{C}$ for the $\mathrm{V}-5 \mathrm{Cr}-5 \mathrm{Ti}$ alloy was investigated to determine stability of the alloy substrate during coating formation by chemical vapor deposition (CVD) or metallic vapor processes at $800-850^{\circ} \mathrm{C}$. Film layers were examined by optical and scanning electron microscopy and by electron-energy-dispersive and $\mathrm{X}$-ray diffraction analysis; they were also tested for electrical resistivity and corrosion resistance. The results elucidated the nature of the coatings, which provided both electrical insulation and hightemperature corrosion protection.
\end{abstract}

\section{Intreduction}

Corrosion resistance of structural materials and magnetohydrodynamic (MHD) force and its influence on thermal hydraulics are major concerns in the design of a liquid-metal cooling system for a firstwall/blanket in a magnetic fusion reactor (MFR). 1,2 Vanadium and V-base alloys ( $\mathrm{V}-\mathrm{Ti}$ or $\mathrm{V}-\mathrm{Ti}-\mathrm{Cr}$ ) are leading candidate materials for structural applications in a fusion reactor. 3 The objective of this study is to develop stable corrosion-resistant coatings, as well as insulator coatings, at the liquid-metal/structuralmaterial interface. Previous studies focused on in-situ formation of AlN on as-received and prealuminided $\mathrm{V}$-alloys in liquid-Li environments. 4,5 Subsequent work addressed in-situ formation of $\mathrm{CaO}$ in a liquid- $\mathrm{Li}$ environment because the electrical resistivity of $\mathrm{CaO}$ is 10,000 times higher than that of AIN, and because $\mathrm{CaO}$ has a high thermodynamic stability in liquid $\mathrm{Li}$ among the available insulator candidates (i.e., $\mathrm{CaO}$, $\mathrm{Y}_{2} \mathrm{O}_{3}, \mathrm{BeO}, \mathrm{MgO}, \mathrm{MgAl}_{2} \mathrm{O}_{4}, \mathrm{Y}_{3} \mathrm{Al}_{2} \mathrm{O}_{12}$, etc.). ${ }^{5-7}$ The coatings should be formable on various shapes such as the inside of tubes or irregular shapes to prevent adverse currents that are generated by MHD forces from passing through the structural walls.
The coatings could also improve general corrosion resistance and act as a diffusion barrier for hydrogen isotopes, viz., deuterium and tritium.

\section{Approaches for Insulator Coatine. Development}

Several experimental steps were employed to develop insulator coatings on V-based alloys, namely (a) screening of selected electrical insulators in liquid Li based on thermodynamic stability, electrical resistivity, coefficients of thermal expansion (CTE), and diffusion coefficients of cations and anions within the coating layer; (b) liquid-Li compatibility tests for candidate electrical insulators; 5,6 and (c) methods of in-situ fabrication of intermetallic coatings in liquid $\mathrm{Li}$ by conversion of an intermetallic layer to an electrical insulator coating in a controlled environment. Failure (cracking or spallation) and self-healing characteristics of the coating layer are also important in MFR applications. This paper presents results on compatibiity of candidate insulators with liquid $\mathrm{Li}$ and fabrication of intermetallic coatings on $\mathrm{V}-5 \% \mathrm{Cr}-5 \% \mathrm{Ti}$.

\section{Solid-State Interactions: Bonding of AlN and Metal/Alloy Substrates}

Solid-state interactions between AIN and several metals and alloys (viz., V, V-5\% Cr-5\% Ti, Ti, and Type 316 stainless steel) were investigated. Sintered discs of $\mathrm{Y}_{2} \mathrm{O}_{3}$-enriched AlN (12.7 $\left.\times 50 \times 9 \mathrm{~mm}\right)$ wore obtained from the Ceramics Section at Argonne National Laboratory. ICP-spectrochemical analysis of the AIN samples indicated the following composition (in wt.\%); $\mathrm{As}<0.05, \mathrm{Ba}=0.005, \mathrm{Be}<0.001, \mathrm{Ca}=0.54$, $\mathrm{Co}<0.002, \mathrm{Cr}<0.002, \mathrm{Cu}=0.006, \mathrm{Fe}=0.015, \mathrm{Y}=3.77$, $\mathrm{Y}_{2} \mathrm{O}_{3}=4.79, \mathrm{Mg}=0.004, \mathrm{Mn}<0.001, \mathrm{Ni}=0.002, \mathrm{~Pb}<$ $0.02, \mathrm{Sb}<0.05, \mathrm{Sn}<0.02, \mathrm{Sr}<0.001, \mathrm{Ti}=0.022$, $\mathrm{V}<0.002, \mathrm{Zn}<0.002, \mathrm{Zr}<0.002$, and $\mathrm{Te}<0.05$. The discs were cut into pieces measuring $=12.7 \times 12.7 \times$ $2.7 \mathrm{~mm}$ and ground flat on Struers 4000 silicon carbide paper. The discs were then ultrasonically cleaned in isopropyl alcohol. A disc of each metal or alloy was placed between two AIN discs and the entire stack was 


\section{DISCLAIMER}

Portions of this document may be illegible in electronic image products. Images are produced from the best available original document. 


\section{DISCLAIMER}

This report was prepared as an account of work sponsored by an agency of the United States Government. Neither the United States Government nor any agency thereof, nor any of their employees, makes any warranty, express or implied, or assumes any legal liability or responsibility for the accuracy, completeness, or usefulness of any information, apparatus, product, or process disclosed, or represents that its use would not infringe privately owned rights. Reference herein to any specific commercial product, process, or service by trade name, trademark, manufacturer, or otherwise does not necessarily constitute or imply its endorsement, recommendation, or favoring by the United States Government or any agency thereof. The views and opinions of authors expressed herein do not necessarily state or reflect those of the United States Government or any agency thereof. 
placed in a furnace. A compressive force was applied to the stack by using a $120^{\circ}$-three-spring-loaded alumina rod on the top of the stack. A detailed description of the apparatus is given elsewhere. ${ }^{7}$ The AlN/alloy stack was annealed in a furnace at $900^{\circ} \mathrm{C}$ for $129 \mathrm{~h}$ in flowing $3 \% \mathrm{H}_{2}-\mathrm{N}_{2}$. After cooling, the specimen stack was examined for indications of strong bonding between AIN/alloy substrates. Interfaces between the alloys and AlN were examined by SEM/EDS to determine diffusion profiles of various elements. Results for the diffusion couples are given below.

V/AIN: V diffused into AIN, but a bond was not formed and VN was not detected. The absence of a good bond and no interdiffusion of $\mathrm{N}$ are not conducive to the development of an adherent coating by a hightemperature process. In this case, a low-temperature physical vapor deposition (PVD) technique could be tried, but if the operating temperature increases or the service time is very long, the base metal (V) could be degraded by formation of vacancies at the metalAlN interface, grain boundaries, and dislocations. Eventually, vacancies would coagulate to form voids within the $\mathrm{V}$ substrate, which could lead to debonding of the coating.

TVALN: Ti did not bond with AIN but a thin layer formed at the TVAIN interface. This is indicative of a $\mathrm{T}_{\mathrm{x}} \mathrm{N}_{\mathrm{y}}$ phase, and some diffusion of $\mathrm{N}$ into $\mathrm{Ti}$ was evident. Bonding of AlN/Ti $\mathrm{N}_{y}$ exhibited sinteringlike behavior; however, $\mathrm{Ti}_{\mathrm{X}} \mathrm{N}_{\mathrm{y}}$ was detached from $\mathrm{Ti}$ in some areas, which indicates outward diffusion of $\mathrm{Ti}$ during formation of $\mathrm{Ti}_{x} \mathrm{~N}_{y}$. These processes are shown in Fig. 1.

Y-5Cr-5Ti/AlN: Neither $\mathrm{V}, \mathrm{Ti}$, nor the $\mathrm{V}$ alloy bonded with AlN. Minimal information was obtained because no bonding occurred. Coarsening of grains in V-5Cr$5 \mathrm{Ti}$ at the alloy/AlN interface was observed, and may have been accelerated by applied pressure.

Type 316 Stainless Steel/AIN: Reaction occurred between a thin oxide scale $\left(\mathrm{Cr}_{2} \mathrm{O}_{3}\right)$ on the Type 316 stainless steel and AlN to form $\mathrm{Al}-\mathrm{Cr}-\mathrm{O}$. AlN particles were found on the surface of the steel, which suggests that a strong bond could be produced in this couple. Dissolved oxygen in the steel transferred to the surface and reacted with AlN to form $\mathrm{Al}-\mathrm{O}-\mathrm{N}$ at the interface. The predicted products from this diffusion couple are AlN/Al-O-N/Al-Cr-O/SS after long-term exposure. Strong bonding formation between Type 316 stainless steel/AlN interface was observed. This couple is applicable to the development of insulator coatings because the ohmic resistance of Al-O-N phase was higher than expected. In the same vein, we may pursue the interaction of oxygen-charged $\mathrm{V}-5 \mathrm{Cr}-5 \mathrm{Ti}$ alloys with AlN to produce a V-5Cr-5Ti-(O)/Al-O-N/AlN couple, which may also reveal enhanced ohmic resistance. Preparation of oxygen-charged in $\mathrm{V}-5 \mathrm{Cr}$ $5 T$ was described previously. ${ }^{8}$

\section{Diffusion Aporoach for In-Situ Formation of Insulator Coatings in Liquid Li}

Ionic diffusion (cation, anion, or both) within the coating must be considered during formation. as should long-term exposure of insulator coatings in liquid-Li environments.

Qutward Cation or Anion Diffusion from Alleys or Ceramic Substrates: In this case, a metal ion (cation) or anion leaves the substrate and migrates to the scale/liquid-metal interface, and a vacancy may be produced at a grain boundary, dislocation, or other active defect area within the substrate (Fig. 2). The consequences of predominantly outward diffusing species at the metal/coating interface are vacancy formation and coalescence (void formation) near the interface, and reduction in the bond strength between coating/substrate. However, if the chemical potential gradient at the coating/substrate is relatively small at elevated temperatures, void formation may not occur. In general, outward cation or anion diffusion from alloys or ceramic substrates should be avoided.

Inward Diffusion via Insulater Layer: If anions of $O$, $N$, (or $C$ ) within the coating layer diffuse inward toward the alloy, insulator-layer growth occurs at the alloy/coating interface. However, diffusion of cations from metal atoms in the liquid environment must also be considered.

\section{Grain-Growth Behavior of V-5\%Cr-5\%Ti}

In coatings produced by high-temperature processes such as CVD or thermally grown layers, grain growth and changes in morphology of the alloy influence the coating properties. ${ }^{8}$ Even though the CTEs of the substrate and coating layer are similar in magnitude, adherent coatings may not form because of inadequate stabilization of alloy substrate. This is more prevalent in the case of brittle ceramic or intermetallic coatings on metallic substrates because of diffusion-related phenomena in the metal (e.g., grain growth) rather than in the ceramic at high processing temperatures. For high-temperature alloys, viable coatings require alloy stabilization before coating application; 9 otherwise, the coating layers tend to spall during hightemperature operation because of grain growth or other morphological changes. In the case of $\mathrm{Fe}-\mathrm{Cr}$ steels, a small amount of $\mathrm{Y}(\approx 0.3 \mathrm{wt} \%)$ in the alloy inhibits grain growth. ${ }^{9}$

The V-5\%Cr-5\%Ti specimens were wrapped in Ta foil, sealed in quartz capsules in vacuo to avoid $\mathrm{Si}$ or $\mathrm{O}$ contamination, and annealed for $0.3-61.3 \mathrm{~h}$ at $1000^{\circ} \mathrm{C}$. Figures 3 and 4 show grain morphology and change in 


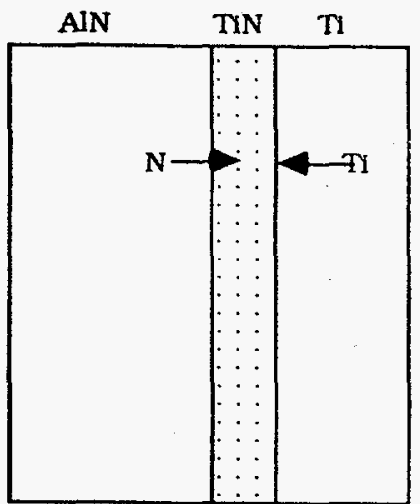

1) $A l N+T i=T_{x} N y+A l N 1-\delta$ initial reaction ( $x$ and $y=1, \delta<1$ )

2) $A l N / A l N_{1-\delta} / T_{x} N_{y} / T i \rightarrow T_{x} N_{y}$ :

layer grows by $N$ diffusion from AlN to $T i$

3) AlN/AlN I- $\delta / T i x N_{y} / T i$ :

$T i$ and $N$ interdiffusion and growth occurs in $T i_{x} N_{y}$ layer; $T i N / T i$ interface bond weakens due to outward diffusion of $T i$

Figure 1: Schematic diagram of solid-state reaction steps at Ti/AlN interface.

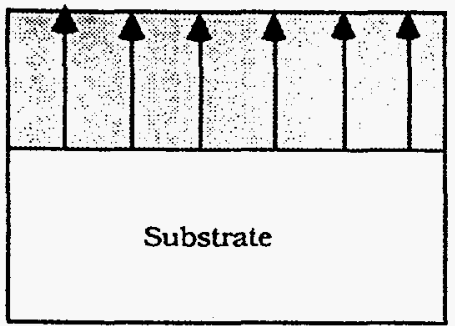

Outward DIflusion

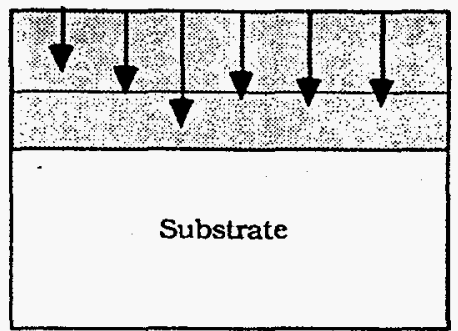

Inward Diffusion

Figure 2: Coating layer formation by different diffusion profiles.

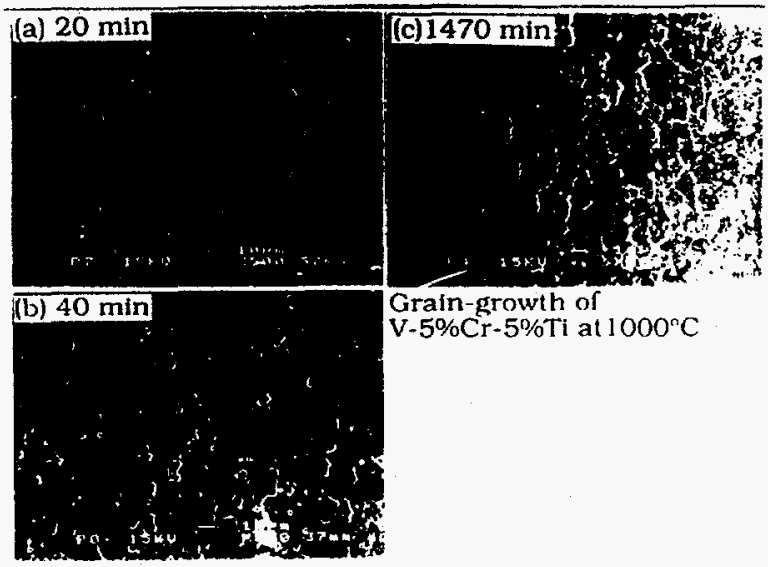

Figure 3: SEM photomicrographs of V-5\%Cr-5\%Ti specimens after annealing several times at $1000^{\circ} \mathrm{C}$ in grain-growth experiments. 


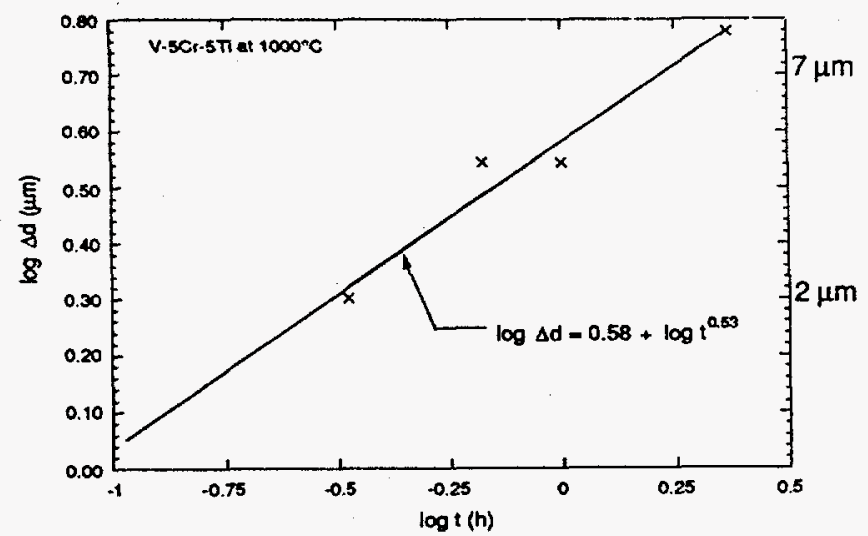

Figure 4: Increase in grain size $(\Delta d, \mu \mathrm{m})$ from as-received value $(7 \mu \mathrm{m})$ for $\mathrm{V}-5 \% \mathrm{Cr}-5 \% \mathrm{Ti}$ specimens as a function of time at $1000^{\circ} \mathrm{C}$.

grain diameter of $\mathrm{V}-5 \% \mathrm{Cr}-5 \% \mathrm{Ti}$ as a function of time, respectively. At $1000^{\circ} \mathrm{C}$, grain growth decreases rapidly after $\approx 2.5 \mathrm{~h}$; the grain size of a specimen annealed for $24 \mathrm{~h}$ is almost the same as the one annealed for $2.5 \mathrm{~h}$. The increase in grain size, $\Delta \mathrm{d}$, was $7 \mu \mathrm{m}$ for an initial average grain size of $7 \mu \mathrm{m}$. Graingrowth behavior at $1000^{\circ} \mathrm{C}$ in terms of $\log \Delta d$ versus log time can be represented by

$$
\log \Delta d=0.58+\log t^{0.53},
$$

where the $=0.5$ exponent of time is indicative of a diffusion mechanism. Based on these results, we expect that grain growth will not have a significant effect on high-temperature coating by process $\%$ such as CVD, pack cementation, or PVD.

\section{Formation of Intermetallic Coatings on High-Temperature Alloys}

Various intermetallic and insulator layers were developed by different methods, namely, CVD, hightemperature PVD, ion-beam-assisted deposition (IBAD), and exposure of specimens to liquid $\mathrm{Li}$ containing dissolved metallic solutes $(\mathrm{Al}, \mathrm{Be}, \mathrm{Mg}, \mathrm{Si}$, $\mathrm{Ca}, \mathrm{Pt}, \mathrm{Y}$, and $\mathrm{Cr}$ ) to form coatings by chemical reaction with constituents in various metals and alloys (Ti, V-5Cr-5Ti, V-Ti, Types of 304 and 316 stainless steel, $\mathrm{Fe}-25 \mathrm{Cr}$ with $0.3 \mathrm{Y}$ or $6 \mathrm{Al}$ ). Most of the solutes in $\mathrm{Li}$ were chosen on the basis of thermodynamic stability of their metal oxides or nitrides in $\mathrm{Li}$, as well as on results of compatibility screening tests for ceramic materials in $\mathrm{Li}$.

\section{Chemical Yapor Depesition}

Aluminide and AIN Coatings: Aluminide coatings that form on structural alloys during exposure to liquid $\mathrm{Li}$ that contained dissolved Al suggesi a means for producing stable electrical insulator layers, such as AlN, by subsequent nitration of the intermetallic layer in the liquid-metal environment. 7 The formation of several aluminides $\left(\mathrm{V}_{\mathrm{X}} \mathrm{Al}_{\mathrm{y}}\right)$ that contain $>40-50$ at. $\%$ $A l$ on $\mathrm{V}$-base alloys can be predicted from the V-Al phase diagram shown in Fig. 5.10,11 These phase relationships are the basis for the formation of aluminide coatings on $\mathrm{V}$ and its alloys. Aluminide coatings were produced on the alloys by CVD at 800 $850^{\circ} \mathrm{C}$ with trimethyl aluminum $\left(\mathrm{CH}_{3}\right)_{3} \mathrm{Al}$ used as the source of $\mathrm{Al}$ to be diffused/reacted on the sample surfaces. In this study, atmospheric-pressure CVD was used because of its utility for engineering applications. Figure 6 is a schematic diagram of the CVD apparatus. The $\left(\mathrm{CH}_{3}\right)_{3} \mathrm{Al}$ vapor was aspirated by a $3 \% \mathrm{H}_{2}$-Ar carrier gas with impurity oxygen and carried via a Ta tube to the high-temperature zone, where the vapor decomposed and reacted with the specimens. The reaction for the formation of aluminides is

$$
\mathrm{V}+3 \mathrm{Al}=\mathrm{Al}_{3} \mathrm{~V},
$$

and the $\Delta G^{\circ}$ range for the reaction is -4 to $-5 \mathrm{kcal} / \mathrm{mole}$ (Fig. 7).

This process was followed by mixing of $\mathrm{NH}_{3}$ into the gas stream to convert the aluminide to an AIN coating according to the reaction

$$
\mathrm{Al}_{3} \mathrm{~V}+\mathbf{N} \rightarrow 3 \mathrm{AlN}+\mathrm{V},
$$

where $\mathrm{N}$ represents nitrogen activity in the gas phase or dissolved in liquid $\mathrm{Li}$. The free energy of formation of AlN is $-45.94 \mathrm{kcal} / \mathrm{mole}$; therefore, the $\Delta \mathrm{G}^{\circ}$ for the reaction in $\mathrm{Eq}$. (3) is $-40.94 \mathrm{kcal} / \mathrm{mole}$ at $700 \mathrm{~K}$. This 


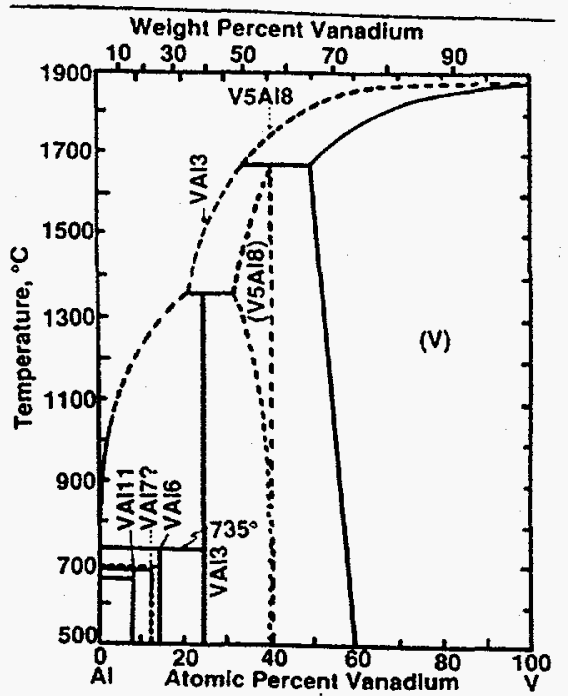

Figure 5: Al-V binary phase diagram.

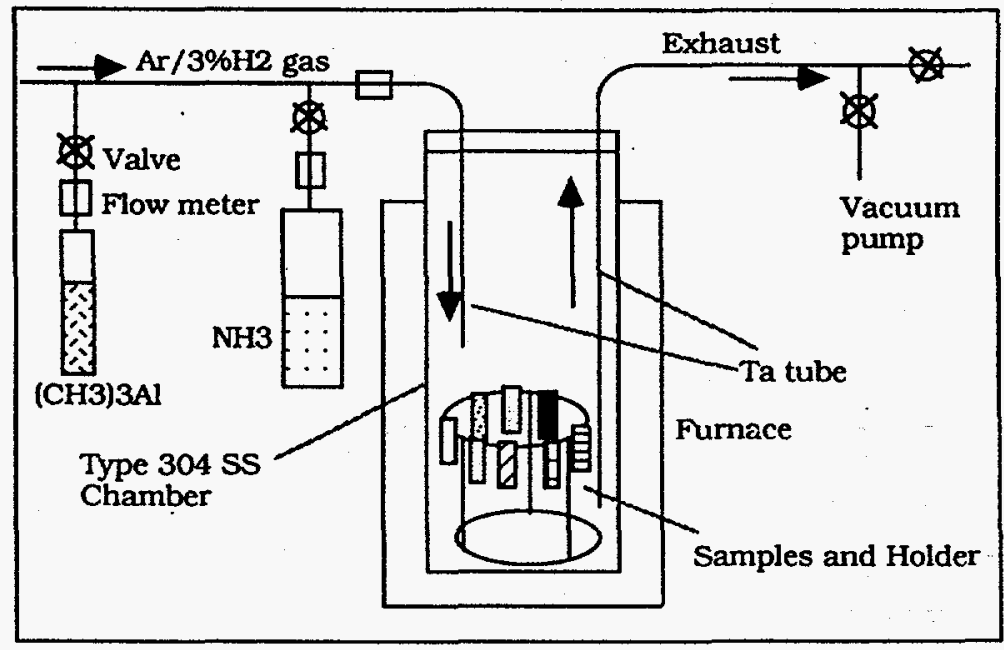

Figure 6: Schematic of CVD apparatus.

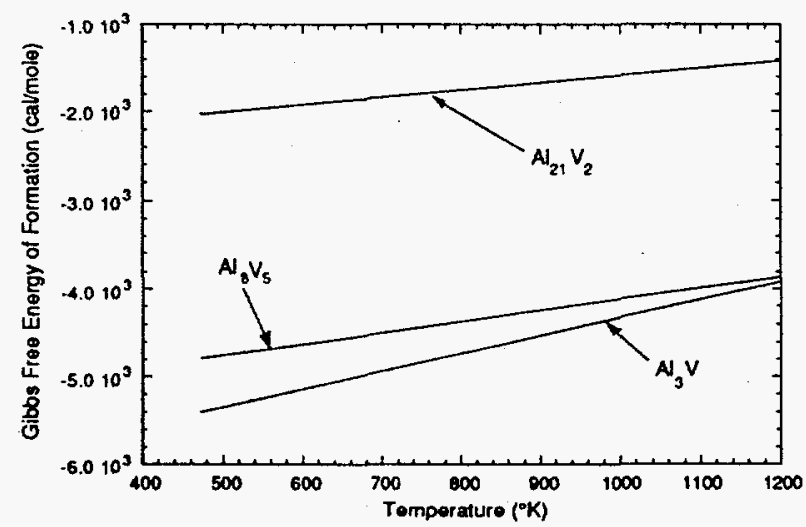

Figure 7: Gibbs free energy of formation for various intermetallic compounds in Al-V system as a function of temperature. 
reaction will occur spontaneously, and the rate-determining step will be ionic diffusion through the nitride layer. Residual $\mathrm{V}$ formed during the reaction will either redistribute within $\mathrm{Al}_{3} \mathrm{~V}$ or $\mathrm{AlN}$ will become enriched in $\mathrm{V}$, depending on the direction of $\mathrm{V}$ diffusion and the thermodynamic stability of $\mathrm{V}_{2} \mathrm{~N}$ near the $\mathrm{Al}_{3} \mathrm{~V} / \mathrm{AlN}$ interface. Because of the high thermodynamic stability of TiN, formation of this phase on aluminided $\mathrm{V}-5 \% \mathrm{Cr}-5 \% \mathrm{Ti}$ is also a possibility."

Figure 7 (a) is an SEM photomicrograph of an intermetallic vanadium aluminide coating on a $\mathrm{V}-5 \mathrm{Cr}$ 5Ti substrate. The chemical composition of the coating surface by electron-energy-dispersive spectroscopy (EDS) is as follows:

$\begin{array}{lrr}\text { Al } & \text { 61.34 at.\% } & (45.72 \text { wt.\%) } \\ \text { V } & 33.57 \text { at.\% } & (47.23 \text { wt.\%) } \\ \text { Cr } & 2.72 \text { at.\% } & (3.91 \text { wt.\%) } \\ \text { TI } & 2.37 \text { at.\% } & (3.13 \text { wt.\%). }\end{array}$

Based on these compositions and the V-Al binary phase diagram (Fig. 1), the composition of the intermetallic phase at the surface lies between $\mathrm{Al}_{3} \mathrm{~V}$ and $\mathrm{Al}_{8} \mathrm{~V}_{5}$. When we consider the free energy of formation of Al-V intermetallic phases (Fig. 7), the $\mathrm{Al}_{3} \mathrm{~V}$ phase should form because of its greater stability, but at high temperatures $\left(850^{\circ} \mathrm{C}, 1123 \mathrm{~K}\right)$ a mixiure of $\mathrm{Al}_{3} \mathrm{~V}$ and $\mathrm{Al}_{8} \mathrm{~V}_{5}$ could arise due to the similar magnitudes of the free energies of formation. However, if $\mathrm{Al}$ concentration is not high enough (e.g., $>40$ at.\%), V-Al intermetallic phases will not form at the surface and Al will only diffuse into the bcc sublattice of $\mathrm{V}$ according to the phase diagram (Fig. 5). Based on our previous work, ${ }^{12} \mathrm{Al}_{3} \mathrm{~V}$ was prevalent on various $\mathrm{V}$-Cr-Ti alloys.

Figure 8 (a) shows an SEM photomicrograph and EDS spectra of an aluminide surface on $\mathrm{V}-5 \% \mathrm{Cr}-5 \% \mathrm{Ti}$ at $850^{\circ} \mathrm{C}$, and Fig. 8(b) shows similar information for an AlN surface formed at $800^{\circ} \mathrm{C}$. The Ta tube that carried the gas into the high-temperature zone was also analyzed. Figure 9 shows the Ta-Al intermetallic and AlN coatings on the inner surface of the tube. CVD in which $\mathrm{AlCl}_{3} / \mathrm{NH}_{3}$ is the source of $\mathrm{Al}$ may not be applicable for many materials because of $\mathrm{Cl}$-induced corrosion. Figure 10 is an SEM photomicrograph of a CVD coating on $\mathrm{V}-5 \% \mathrm{Cr}-5 \% \mathrm{Ti}$ at $850^{\circ} \mathrm{C}$ where $\mathrm{AlCl}_{3}$ was used. When vanadium chloride compounds form during the coating process, they tend to spall and prevent the formation of an adherent AlN layer at the surface.

*When we exposed prealuminide $\mathrm{V}-5 \mathrm{Cr}-5 \mathrm{Ti}$ to liquid $\mathrm{Li}$ containing $100-200 \mathrm{ppm}$ N, TiN grew outward between the aluminide grains.

\section{$\mathrm{Al}_{2} \mathrm{Q}_{3}$ Coatings on Stainless Steels in Air}

Low rates of elemental diffusion and electron transport in $\mathrm{Al}_{2} \mathrm{O}_{3}$ are desirable properties for high-temperature corrosion-resistant coatings. However, benefits from these properties for high-temperature coating applications are rather limited because crack-free $\mathrm{Al}_{2} \mathrm{O}_{3}$ coatings are extremely difficult to fabricate. In this study, we have had some success in forming $\mathrm{Al}_{2} \mathrm{O}_{3}$ coatings on Types 304 and 316 stainless steel. Coatings were produced by growing an intermetallic aluminide layer (FeAl) on the steels in liquid $\mathrm{Li}$ containing 4-5 wt.\% dissolved $\mathrm{Al}$, followed by oxidation of the aluminide layer in air at $1000^{\circ} \mathrm{C}$. Figure 11 shows circular and longitudinal cross sections of an 0.5-in.-diameter Type 304 stainless steels tube in which the aluminide coating layer on the inside surface was oxidized in air for $72 \mathrm{~h}$ at $1000^{\circ} \mathrm{C}$. To determine the minimum required $\mathrm{Al}$ content of the steel to form an $\mathrm{Al}_{2} \mathrm{O}_{3}$ coating layer, samples of aluminided steel tube were sectioned and polished and an $\mathrm{Al}$ depth profile was measured by EDS (detection limit of $\approx 1$ at.\%). After oxidation, an $\mathrm{Al}$ spectrum from EDS analysis indicated a continuous $\mathrm{Al}_{2} \mathrm{O}_{3}$ coating layer had formed. Figure 12 shows $\mathrm{Al}_{2} \mathrm{O}_{3}$ coating layers formed on the inside of other Type 304 stainless steel tubes.

Based on our previous experience, most $\mathrm{Al}_{2} \mathrm{O}_{3}$ coating layers formed on $\mathrm{Fe}-\mathrm{Cr}$-Al alloys contained numerous cracks, mainly due to mismatch of the C.TE $\quad \approx 8 \mathrm{x}$ $10^{-6} / \mathrm{K}$ for $\mathrm{Al}_{2} \mathrm{O}_{3}$ and $\approx 17 \times 10^{-6} / \mathrm{K}$ for stainless stee $)$. We believe that $\mathrm{Li}(130 \mathrm{ppm})$ in the aluminide layer that formed in liquid $\mathrm{Li}$ containing $\mathrm{Al}$ plays a role in accommodating thermal stresses during $\mathrm{Al}_{2} \mathrm{O}_{3}$ growth and cooling because of fast diffusion of $\mathrm{Li}^{+}$ions due to their small size.

\section{High-Temperature Metallic Me Vapor Deposition of Mro Coating}

$\mathrm{MgO}$ is another potential candidate for an insulator coating in a liquid-Li blanket of an MFR. An MgO coating could be applied by various components by vapor deposition because metallic $\mathrm{Mg}$ has a high vapor pressure at elevated temperatures. This coating method was investigated with the apparatus similar to that shown in shown in Fig. 6. Mg vapor was generated in a high-temperature Knudsen cell located at the bottom of the stainless steel chamber, which provided a homogeneous source of $\mathrm{Mg}$ vapor. $\mathrm{Mg}$ was contained in a tungsten or Type 304 stainless steel boat and covered with a plate containing a small hole ( $=1.5-\mathrm{mm}$-diameter pinhole). Sublimation of $\mathrm{Mg}$ in a relatively low vacuum of $10^{-3}$ to $10^{-4}$ torr, in which $\mathrm{O}_{2}$ was present as an impurity, enabled the formation of $\mathrm{MgO}$ clusters by oxidation of $\mathrm{Mg}$ vapor inside the chamber. After coating the $\mathrm{V}-5 \mathrm{Cr}-5 \mathrm{Ti}$ specimens at $800^{\circ} \mathrm{C}$, the system was cooled to room temperature by 


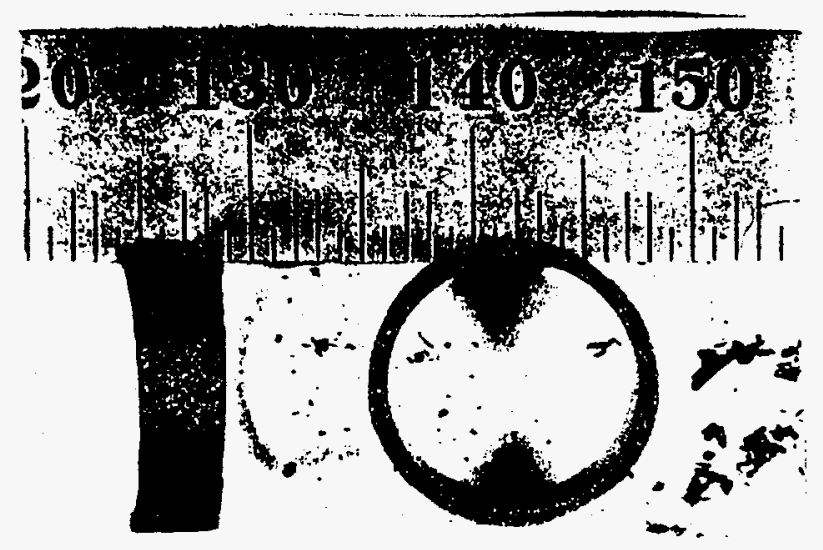

Figure 11: $\mathrm{Al}_{2} \mathrm{O}_{3}$ coating by air oxidation of 0.5 -in.-diameter aluminided Type 304 stainless steel tube at $1000^{\circ} \mathrm{C}$.

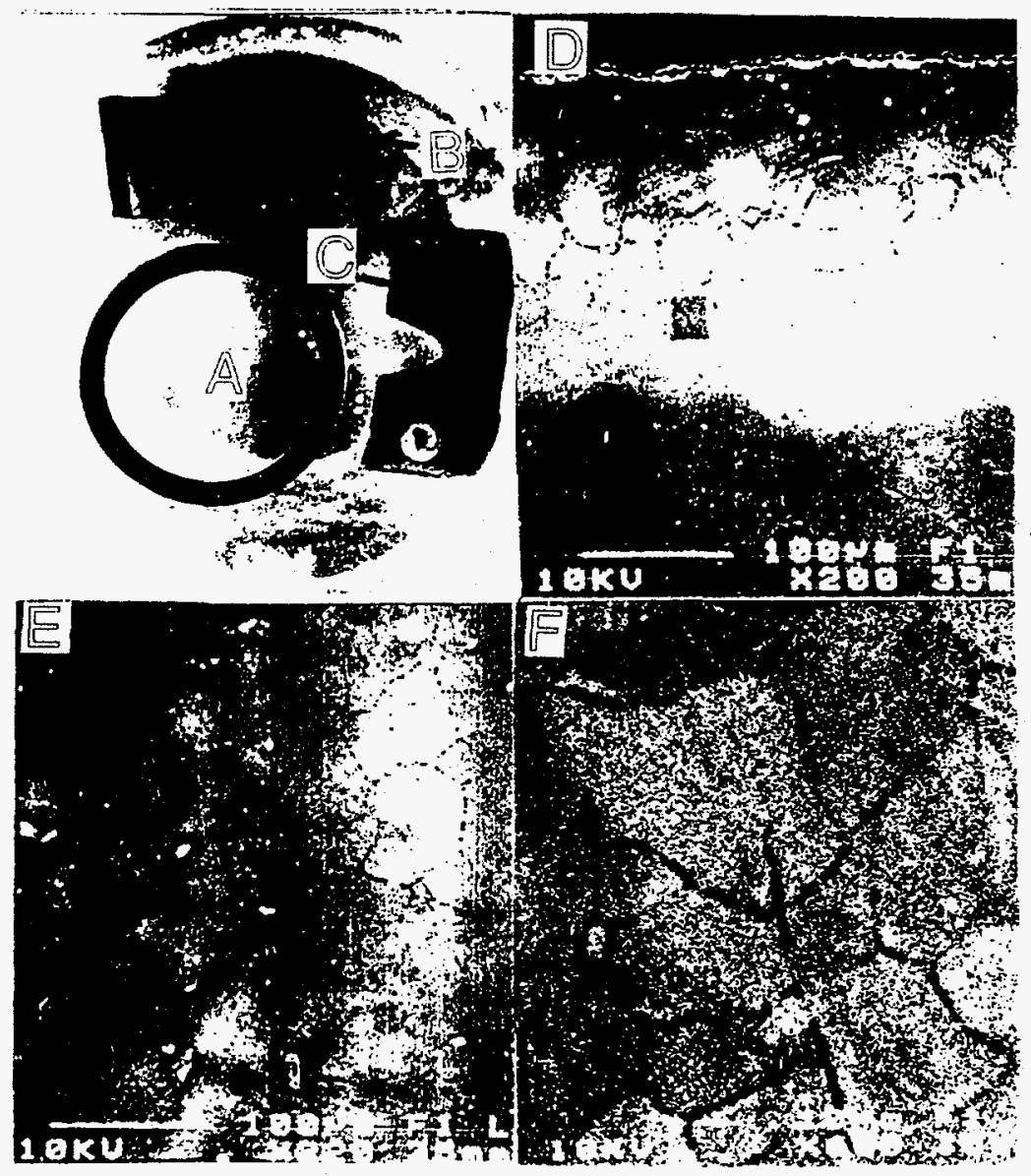

Figure 12. $\mathrm{Al}_{2} \mathrm{O}_{3}$ coating by air oxidation of aluminided Type 304 stainless steel tube at $1000^{\circ} \mathrm{C}$ : (a) cross section of tube, (b) longritudinal cross section of tube, (c) polished region near outside surface of tube to investigate grain-boundary penetration of oxygen, (d) view of extended scalc of (b), (c) vicw of extended scale of (c), and (f) details of $(e)$ by batck-scattered electron imatur. 


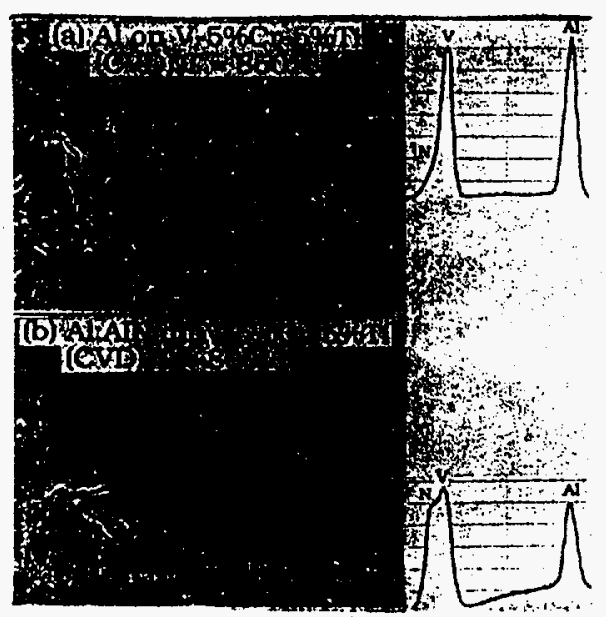

Figure 8: SEM/EDS photomicrographs of (a) aluminide coating on $\mathrm{V}-5 \mathrm{Cr}-5 \mathrm{Ti}$, and (b) Al/AIN coating.

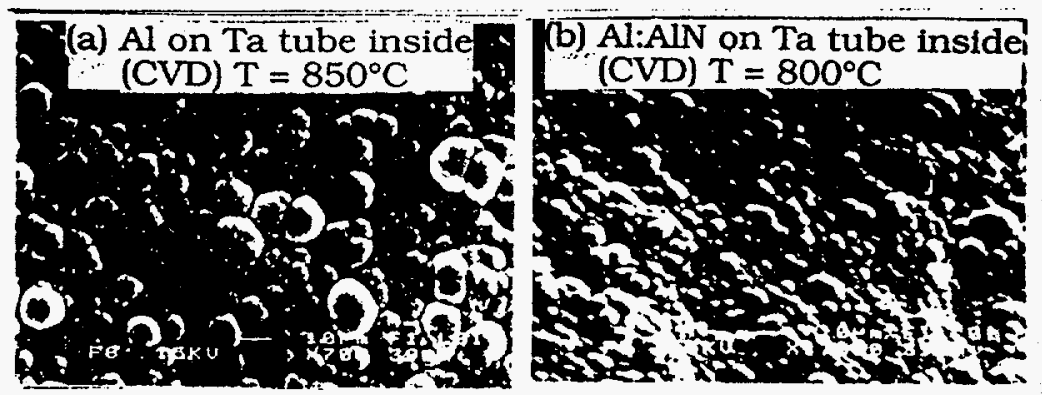

Figure 9: SEM photomicrograph of (a) aluminide coating, and (b) AVAIN coating on inside surface of Ta tubes.

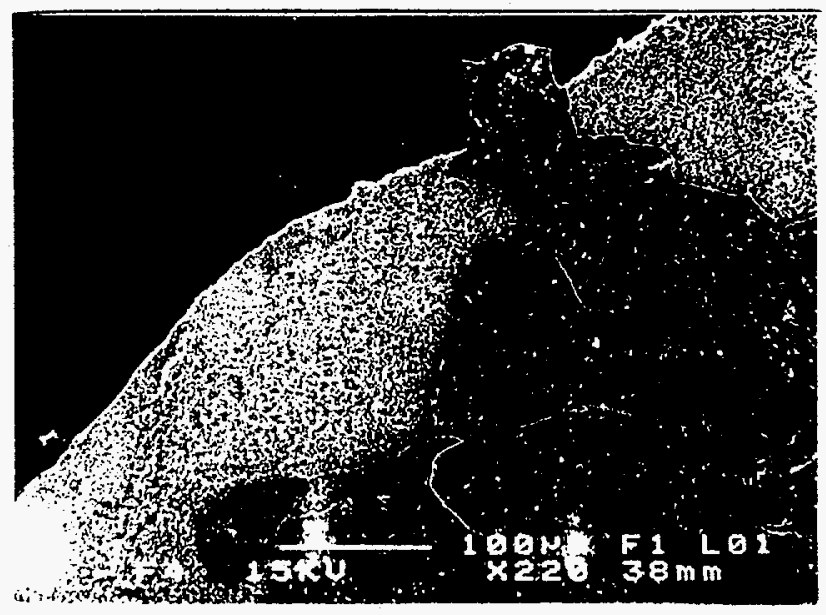

Figure 10: AIN (onting produced by $\mathrm{CVI}$ ) with $\mathrm{AlCl}_{3} \mathrm{NH}_{3}$ showing heavy spallation (light areat $V$ - (l compound) and V-Al-N coating adarti are:al 
purging with Ar (99.999\%). The ohmic resistance of the coatings was measured at room temperature and the coatings were evaluated by SEM/EDS. Figure 13 shows a typical MgO coating on V-5Cr-5Ti (a), and its EDS spectrum is shown in Fig. 13 (b). The measured two-point contact resistance at room temperature is $>10^{12} \Omega$. This coating technique could be extended to other oxides, e.g., $\mathrm{CaO}, \mathrm{BeO}, \mathrm{MgAl}_{2} \mathrm{O}_{4}, \mathrm{Y}_{3} \mathrm{Al}_{2} \mathrm{O}_{12}$.

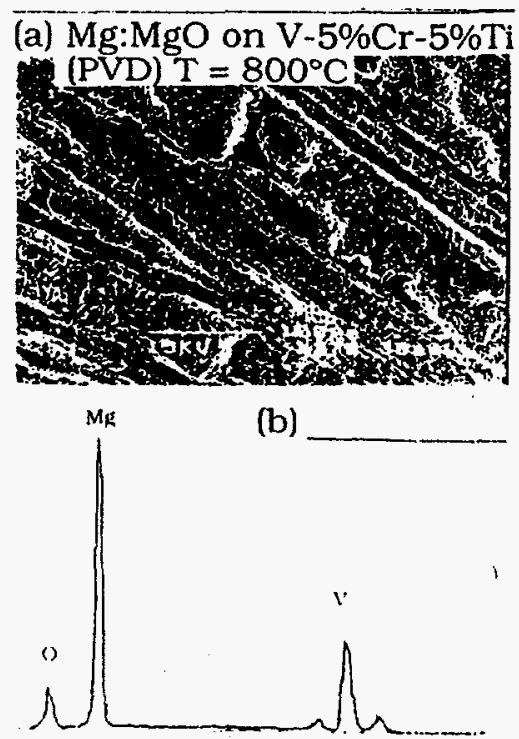

Figure 13: (a) $\mathrm{MgO}$ coating on $\mathrm{V}-5 \mathrm{Cr}$ $5 T i$ and (b) EDS of (a).

\section{Conclusions}

High-temperature couples between AIN and V-alloys, $\mathrm{Ti}$, and Types 304 and 316 stainless steel showed different interface bonding behaviors. Basically, $V$-alloy/AlN couples did not bond. In the case of Ti/AlN, TiN formed at the interface, but the bonding strength was too low and separation occurred at the $\mathrm{Ti} / \mathrm{TiN}$ interface. Strong bonds were obtained between AlN and the stainless steels, but mismatch in the thermal expansion coefficients caused fracture in the relatively thick AIN layer above the alloy/AlN interface.

Intermetallic films were prepared on $\mathrm{V}$-alloys and Types 304 and 316 stainless steel by chemical vapor deposition, high-temperature metallic vapor deposition, and liquid-metal processing in the temperature range of $800-850^{\circ} \mathrm{C}$. The films were examined by optical and scanning electron microscopy and by electron-energy-dispersive and X-ray diffraction analysis. Aluminide films containing $>45 \mathrm{wt} . \% \mathrm{Al}$ and AlN were produced on $\mathrm{V}$-alloys by CVD. The aluminide films on Types 304 and 316 stainless steel were converted to $\mathrm{Al}_{2} \mathrm{O}_{3}$ by oxidation in air at high temperature. The results elucidated the nature of the coatings, which provided both electrical insulation and high-temperature corrosion protection.

\section{Acknowlederments}

The authors appreciate discussions with Dr. T. F. Kassner. This work was supported in part by the Division of Educational Programs at Argonne National Laboratory during a summer research appointment of W. D. Cho. B. Tani of the Argonne Analytical Chemistry Laboratory provided the X-ray diffraction results. G. Dragel and R. W. Clark assisted in the experimental work.

\section{References}

1. C. C. Baker et al., "Tokamak Power System Studies FY 1985," Argonne National Laboratory Report ANL/FPP-85-2 (1985).

2. T. Kammash, Eusion Reactor Physics, Chapter 15, Ann Arbor Science Pub. Inc., Ann Arbor, MI (1975), pp. 405-439.

3. R. F. Mattas, B. A. Loomis, and D. L. Smith, "Vanadium Alloys for Fusion Reactor Applications," JOM, 44(8), 26 (1992).

4. J.-H. Park, T. Domenico, G. Dragel, and R. W. Clark, "Development of Electrical Insulator Coatings for Fusion Power Applications," Proc. 3rd Intl. Symp. on Fusion Nuclear Technology (ISNFT), June 27-July 1, 1994, Los Angeles, CA.

5. J.-H. Park and G. Dragel, "Development of Aluminide Coatings on Vanadium-Base Alloys in Liquid Lithium," Fusion Reactor Materials Semiannual Progress Report for the Period Ending March 31, 1993, DOE/ER-0313/14, pp. 405-410 (1993).

6. R. J. Lauf and J. H. DeVan, "Evaluation of Ceramic Insulator for Lithium Electrochemical Reduction Cells," J. Electrochem. Soc, 139, 2087-2091 (1992).

7. J.-H. Park and G. Dragel, "Development of Electrical-Insulator Coatings: In-situ Electrical Resistance Measurements on $\mathrm{V}-5 \% \mathrm{Cr}-5 \% \mathrm{Ti}$ in Liquid Lithium," Fusion Reactor Materials Semiannual Progress Report for the Period Ending September 30, 1993, DOE/ER-0313/15 (1993).

8. J.-H. Park, "Surface Modification of HighTemperature Alloys," Mat. Technolegy, 9, 9/10 (1994). 
9. J.-H. Park, "Surface Modification of HighTemperature Alloys," The Electrochem. Soc. 186th Meeting, The D. Douglass Symposium on High-Temperature Corrosion, Oct. 9-14, 1994, Miami, FL.

10. M. Hansen, "Constitution of Binary Alloys," MeGraw-Hill, New York (1958)
11. F. A. Shunk, "Constitution of Binary Alloys, Second Supplement," McGraw-Hill, New York (1969).

12. J.-H. Park, "Intermetallic and Electrical Insulator Coatings on High-Temperature Alloys in Liquid Lithium Environments," Proc. Symposium on High-Temperature Coatings-I, TMS Fall Meeting, Oct. 2-6, 1994, Rosemont, IL. 